\title{
HLA-G 3142C/G polymorphism is related to development of symptoms in HTLV-1 infected individuals
}

\author{
Daiani C Cilião-Alves', Maurício C Rocha-Junior ${ }^{2,3^{*}}$, Rodrigo Haddad ${ }^{4}$, Virgínia MD Wagatsuma², \\ Osvaldo M Takayanagui ${ }^{1}$, Dimas T Covas ${ }^{1,2}$, Simone Kashima ${ }^{2,3}$, Eduardo A Donadi ${ }^{1}$ \\ From 16th International Conference on Human Retroviruses: HTLV and Related Viruses \\ Montreal, Canada. 26-30 June 2013
}

The majority of HTLV-1 infected individuals remain asymptomatic (HAC) throughout life, and the risk factors associated to the development of related diseases, such as HAM/TSP and ATL, are not fully understood. The human leukocyte antigen-G (HLA-G) is expressed in several pathological conditions and it has been associated to immunosuppressive effects allowing the virusinfected cells to escape of the host antiviral defense. Here, we evaluated the correlation between HLA-G polymorphisms in symptomatic and asymptomatic HTLV-1 infected individuals. Four polymorphisms of the exon 8 of the HLA-G gene were analysed by gene sequencing in HAC $(n=48)$ and HAM/TSP patients $(\mathrm{n}=43)$. No difference was found between the groups for $3035 \mathrm{C} / \mathrm{T}, 3187 \mathrm{~A} / \mathrm{G}$ and $3196 \mathrm{C} / \mathrm{G}$ polymorphisms. On the other hand, despite of the absence of statistical significance, HAC group showed higher frequency of the 3142GG genotype (responsible for decreased transcription of theHLA-G) compared to HAM/TSP group $(\mathrm{p}=0,0607)$. Still, HAC group showed lower frequency of the 3142CC genotype (responsible for increased transcription of the HLA-G) compared to HAM/TSP group $(\mathrm{p}=0,0762)$. Furthermore, HAC group showed statistically higher frequency of the $3142 \mathrm{G}$ allele and lower frequency of the $3142 \mathrm{C}$ allele compared to HAM/TSP group $(p=0,0244)$. In conclusion, HTLV-1-related symptoms in HAM/TSP group could be partially determined by higher expression of HLA-G (caused by higher frequency of the $3142 \mathrm{C}$ allele). We hypothesise that the higher expression of HLA-G protects the HTLV-1 infected cell against

\footnotetext{
* Correspondence: mauricio_crj@hemocentro.fmrp.usp.br

${ }^{2}$ Fundação Hemocentro de Ribeirão Preto, Ribeirão Preto, São Paulo, Brazil
}

Full list of author information is available at the end of the article immune system attack the increasing proviral load and trigger the HAM/TSP symptoms.

\section{Financial support \\ FUNDHERP, FAPESP and CNPq.}

\section{Authors' details}

${ }^{1}$ Faculdade de Medicina de Ribeirão Preto - USP, Ribeirão Preto, São Paulo,

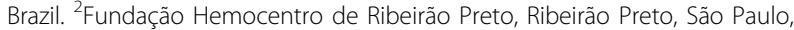
Brazil. ${ }^{3}$ Faculdade de Ciências Farmacêuticas de Ribeirão Preto - USP, Ribeirão Preto, São Paulo, Brazil. ${ }^{4}$ Universidade de Brasília, Faculdade de Ceilândia - UNB/FCE, Brasília, Distrito Federal, Brazil.

Published: 7 January 2014

doi:10.1186/1742-4690-11-S1-P74

Cite this article as: Cilião-Alves et al:: HLA-G 3142C/G polymorphism is related to development of symptoms in HTLV-1 infected individuals. Retrovirology 2014 11(Suppl 1):P74.

Submit your next manuscript to BioMed Central and take full advantage of:

- Convenient online submission

- Thorough peer review

- No space constraints or color figure charges

- Immediate publication on acceptance

- Inclusion in PubMed, CAS, Scopus and Google Scholar

- Research which is freely available for redistribution

Submit your manuscript at www.biomedcentral.com/submit
() Biomed Central 